Sains Malaysiana 49(12)(2020): 3169-3177

http://dx.doi.org/10.17576/jsm-2020-4912-28

\title{
The Influence of Temperature and Electroforesis Deposition Green Inhibitor on Bipolar Plate AA5052 in Sulfuric Acid Medium
}

(Pengaruh Suhu dan Endapan Elektroforesis Perencat Hijau pada Plat Dwikutub AA5052 dalam Asid Sulfurik)

\author{
I Gusti Ayu Arwati, Edy Herianto Majlan*, Loh Kee Shyuan, Teuku Husaini, Sagir Alva, Muhajirin \& \\ NABILAH AFIQAH MOHD RADZUAN
}

\begin{abstract}
Aluminum alloy 5052 (AA5052) contains $\mathrm{Mg}$ (2.2-2.8.8\% weight), Cu (0.1\% weight), Cr (0.15\% weight), Zn (0.1\% weight), Si and $\mathrm{Fe}(0.45 \%$ weight) compositions. This material has been widely used as a bipolar plate in Proton exchange Membrane (PEMFC) fuel cells. This material has several advantages such as: lightness, high conductivity, good tensile strength, and flexibility. PEMFC operations produce several by-products, such as water and heat. Generally, the operation of PEMFC is around 333-353 K and the environment is acidic. In this condition the bipolar plate AA5052 will easily experience rust, thus lowering the performance of the PEMFC. In this study, $0.5 \mathrm{~g} / \mathrm{L} \mathrm{Arabic}$ Gum (AG) used as a green inhibitor and coated onto the AA5052 surface through electrophoretic deposition (EPD). The corrosion test was performed in $0.5 \mathrm{M} \mathrm{H}_{2} \mathrm{SO}_{4}(\mathrm{pH} 2)$ solution under the simulated PEMFC condition. Scanning electron microscopy (SEM) was used to analyze the morphology, and potentiodynamic polarization to determine the corrosion rate. Result shows that AG coating can reduce $60 \%$ the corrosion rate of AA5052 after immersed in 0.5 $\mathrm{M} \mathrm{H}_{2} \mathrm{SO}_{4}$ for $168 \mathrm{~h}$. The effect of temperature on the inhibition efficiency reached $14.4 \%$ under the same condition. $A G$ can be used as a green inhibitor to reduce the corrosion rate of AA5052 bipolar plate.
\end{abstract}

Keywords: Aluminum alloy 5052; Arabic Gum inhibitor; corrosion rate; electrophoretic deposition

ABSTRAK

Aloi aluminium 5052 (AA5052) mengandungi komposisi $\mathrm{Mg}(2.2-2.8 .8 \%$ berat), Cu (0.1\% berat), Cr (0.15\% berat), $\mathrm{Zn}(0.1 \%$ berat), Si dan Fe $(0.45 \%$ berat). Bahan ini telah digunakan secara meluas sebagai plat dwikutub untuk sel fuel membran pertukaran proton (PEMFC). Bahan ini digunakan kerana kelebihannya, seperti ringan, kekonduksian tinggi, kekuatan tegangan yang baik dan kefleksibilannya. Operasi PEMFC menghasilkan beberapa produk sampingan seperti air dan haba. Secara amnya, PEMFC beroperasi pada suhu 333-353 K dan mempunyai persekitaran yang berasid. Plat dwikutub AA5052 ini akan mudah mengalami karat, sehingga menurunkan prestasi PEMFC. Dalam kajian ini, $0.5 \mathrm{~g} / \mathrm{L}$ Gam Arab (GA) digunakan sebagai perencat hijau dan dilapisi ke permukaan AA5052 melalui pemendapan elektroforetik (EPD). Ujian kakisan dilakukan dalam larutan $0.5 \mathrm{M} \mathrm{H}_{2} \mathrm{SO}_{4}(\mathrm{pH}$ 2) sesuai dengan simulasi keadaan PEMFC. Mikroskopi elektron imbasan (SEM) digunakan untuk menganalisis morfologi dan polarisasi potensiodinamik untuk menentukan kadar kakisan. Hasil menunjukkan bahawa lapisan AG dapat mengurangkan 60\% kadar kakisan AA5052 setelah direndam dalam $0.5 \mathrm{M} \mathrm{H}_{2} \mathrm{SO}_{4}$ selama $168 \mathrm{jam}$. Kesan suhu pada kecekapan penghambatan mencapai $14.4 \%$ dalam keadaan yang sama. AG boleh digunakan sebagai perencat hijau untuk mengurangkan kadar kakisan AA5052.

Kata kunci: Aloi aluminium 5052; kadar kakisan; pemendapan elektroforesis; perencat Gam Arab

\section{INTRODUCTION}

PEMFC consists of three main components: Membrane electrode assembly (MEA), bipolar plate, and sealing material. The bipolar plate is the main component that connects cells electricity, structures and aids to piles, uniformly reactive gas distribution, automatic heating, and removing air from the cathode, require constant corrosion. Bipolar plates are made of graphite, a material that has good electrical conductivity and corrosion besides, graphite can be penetrated by gas, but has low resistance to collision and vibration, and this disadvantage is not suitable for use in fuel cell piles and also expensive production. Therefore, metal is a suitable candidate to be used as a bipolar plate (Arwati et al. 2019; Chiang et al. 2014). 
In general, AA5052 is used as bipolar plate in fuel cell technologies, such as proton-exchange membrane fuel cell (PEMFC). PEMFC produces electrical energy with water and stream (313-353 K) as by products (PechRodríguez et al. 2014; Sutharssan et al. 2017; Zhang et al. 2011). The acidity of water and its flow can damage the separator (i.e. Nafion) and enhance the corrosion reaction in bipolar plates, especially at the cathode side. This issue must be controlled so PEMFC can be operated for long term (Corrosion can actually be controlled using a coating method i.e. electrophoretic deposition (EPD) for protecting materials from environmental condition. In principle, EPD is an electrochemical method used to process a coating material through deposition, forming a thin layer on the material surface (Taherian 2014; Vadivelan et al. 2015). Thin layer acts as a protector (inhibitor) on the metal surface to prevent the direct contact between the metal and the environment (Arwati et al. 2018; Bhowmik et al. 2016; Choudhary et al. 2017).

Inorganic inhibitors, such as chrome $(\mathrm{Cr})$ and arsenic (As), are generally applied to prevent the corrosion reaction in a metal. However, chromate and arsenic have toxicity properties, which negatively affect the environment (Gharavi et al. 2015; González Gutiérrez et al. 2018; Huang et al. 2016; Khan et al. 2015). AG is one of the organic materials included in the carbohydrate polymer group. AG is nontoxic to the environment, biodegradable, and biocompatible. Polar elements, such as oxygen $(\mathrm{O})$, nitrogen $(\mathrm{N})$, sulfur $(\mathrm{S})$, and phosphorus $(\mathrm{P})$, are present in AG. All elements can be adsorbed onto the metal surface either naturally or electrochemically (Ameh 2014; Azzaoui et al. 2017; Huang et al. 2016; Sagir et al. 2018).

In a previous study, $0.5 \mathrm{~g} / \mathrm{L}$ AG was coated at AA5052 and stainless steel. AA5052 and stainless-steel using $A G$ where the test used the immersion method in acid solution $\left(0.5 \mathrm{M} \mathrm{H}_{2} \mathrm{SO}_{4}\right)$ for $168 \mathrm{~h}$. The results showed that AG can reduce the corrosion rate of AA5052 and fertilizer and show inhibition efficiency of 79 and $16.98 \%$ (Arwati et al. 2019). There has been no previous research using EPD techniques using AG materials to coat metals.

In the present work, AG was coated onto AA5052 surface by EPD. To describe the PEMFC environment condition, we used $0.5 \mathrm{H}_{2} \mathrm{SO}_{4}$ solution $(\mathrm{pH}=1.0-4.0)$ in accordance with the condition simulation in various studies (Arwati et al. 2019; Bhowmik et al. 2016; Dariva \& Galio 2014; Umoren \& Eduok 2016; Yang et al. 2011).

\section{MATERIALS AND METHODS}

\section{METAL PREPARATION AND SOLUTION PREPARATION}

AA5052 with size of $20 \mathrm{~mm} \times 20 \mathrm{~mm} \times 2.5 \mathrm{~mm}$ was used for testing. The AA5052 plate was drilled to make a hole so the conductive cable can be attached. Prior to EPD, the AA5052 plate surface was initially cleaned and polished using sandpaper with grids of 200, 400, 600, 1000 , and 2000. The plate was washed using acid and base pickling solution and rinsed using deionized water (DW) and acetone.

Solution was prepared using three types of materials, namely, $500 \mathrm{mg}$ of AG, $1000 \mathrm{~mL}$ of deionized water (DW), and pickling solution. AG solution was prepared by dissolving AG into $1000 \mathrm{~mL}$ of deionized water. AG produced from acacia tree was supplied by SIGMA No. G9752-500 kg. Preparation of 0.5 $\mathrm{M} \mathrm{H}_{2} \mathrm{SO}_{4}$ corrosive media was performed using $27.19 \mathrm{~mL}$ of $\mathrm{H}_{2} \mathrm{SO}_{4}(98 \%)$ which was then added to $1000 \mathrm{~mL}$ of distilled water. Solutions for cleaning metal surfaces to remove impurities are made according to American Society for Testing and Materials (ASTM 1994) standards, where the solution consists of acids and bases. The acid solution, to remove fat impurities on the metal surface, consists of 3.13-23.75 mL of hydrofluoric acid (HF), 62.5$93.75 \mathrm{~mL}$ of nitrate, and $500 \mathrm{~mL}$ of deionized water. The alkaline solution to prepare the neutral metal surface consists of 2.75-9.37 g of sodium hydroxide $(\mathrm{NaOH})$, 0.1-0.5 g of sodium phosphate $\left(\mathrm{Na}_{2} \mathrm{HPO} 4\right)$, and $500 \mathrm{~mL}$ of deionized water.

The coating process using electrodeposition technique (EPD) is a metal plating technique by utilizing deposits formed on metal surfaces by moving particles in solution and moving to metal surfaces due to electric field and forming a thin layer that protects the direct contact of Al 5052 surface with the environment. The power supply voltage is $20 \mathrm{~V}$ (20 V DC Power Supply). The mechanism of action of the coating is done by placing a plate of AA5052 into a volumetric glass filled with 500 $\mathrm{mg}$ of Arabic Gum. EPD is performed in two electrode configurations, where AA5052 acts as a working electrode (WE) and a platinum rod (Pt) acts as a counter electrode (CE). The overall EPD processing for AA5052 was performed for 15,30 , and $45 \mathrm{~min}$, and the products were each denoted as AA5052-15, AA5052-30, and AA5052-45. The uncoated AA5052 is called AA5052-0. Three different times were selected to minimize analytical errors and determine the best immersion time during EPD. The AA5052 plate with the lowest corrosion rate was selected for further experimentation and evaluation at different temperatures (Azzaoui et al. 2017; Choudhary et al. 2017; Dalo et al. 2012).

\section{CORROSION RATE TEST}

Corrosion rate was determined using weight lost and electrochemical methods. Electrochemical method was performed using Potentiostat CS350. The uncoated and AG-coated AA5052 plates were immersed in $0.5 \mathrm{M}$ $\mathrm{H}_{2} \mathrm{SO}_{4}$ (pH 1 to $\mathrm{pH} 4$ ) for 72,120 , and $168 \mathrm{~h}$ at 298, 313, 333 , and $353 \mathrm{~K}$ to detect the ability of $\mathrm{AG}$ to protect against corrosion. Corrosion rate was calculated using weight loss test, as described in (1) (Dalo et al. 2012): 


$$
C R=\frac{m_{1}-m_{2}}{A . t}
$$

where $C R$ is the corrosion rate $\left(\mathrm{mg} / \mathrm{cm}^{2} \mathrm{~h}\right) ; m_{1}$ and $m_{2}$ $(\mathrm{mg})$ are the weights of the specimens before and after immersion, respectively; $A\left(\mathrm{~cm}^{2}\right)$ is the contact area of the specimen, and $t(\mathrm{~h})$ is the immersion time. Inhibition efficiency (IE) was determined using (2):

$$
\% I E=\frac{\text { CRblank }- \text { CRinh }}{\text { CRblank }} \times 100 \%
$$

where $C R_{\text {blank }}$ and $C R_{i n h}$ are the weight reduction of the sample without and with the inhibitor; and $I E$ is the inhibition efficiency (\%). In addition, electrochemical methods were used to evaluate corrosion rate and inhibition efficiency. Electrochemical tests were performed using Potentiostat (CS350 type). These tests were conducted to determine the passivation of the material, the corrosion potential $\left(E_{\text {corr }}\right)$, and the corrosion current density $\left(I_{\text {corr }}\right)$. Potentiodynamic polarization test was conducted at different potentials within -0.6 to $1.5 \mathrm{~V}$ at 2.0 $\mathrm{mV} / \mathrm{s}$ scan rate to determine the passivation of the material while. The potential of -0.9 to $-0.1 \mathrm{~V}$ and the scan rate of $2.0 \mathrm{mV} / \mathrm{s}$ were used to determine $\mathrm{E}_{\text {corr }}$ and $\mathrm{I}_{\text {corr }}$. Based on ASTM G102 (1999), CR can be calculated using (3):

$$
C R=K 1 \times \frac{\text { Icorr }}{\rho} x E W
$$

where $C R$ is the corrosion rate (mill per year, mpy); $K_{1}$ is the conversion constant $\left(0.1288 \mathrm{mpy} . \mathrm{g} / \mathrm{A} . \mathrm{cm}^{2}\right) ; I_{\text {corr }}$ is the corrosion current density $\left(\mathrm{A} / \mathrm{cm}^{2}\right) ; \rho\left(\mathrm{g} / \mathrm{cm}^{3}\right)$ is the density of the material; and $E W(\mathrm{~g} / \mathrm{mol})$ is the weight equivalent of the material. Equation (4) was then used to determine the inhibition efficiency of AG:

$$
I E=\frac{\text { Iblank-Iinh }}{\text { Iblank }} \times 100 \%
$$

where $I_{\text {blank }}$ and $I_{\text {inh }}\left(\mathrm{A} / \mathrm{cm}^{2}\right)$ are the corrosion current density of the sample without and with the inhibitor, and $I E(\%)$ is the inhibition efficiency.

\section{SEM ANALYSIS}

Scanning electron microscopy (SEM) analysis was performed to characterize the morphology of the materials by using MA10 Carl Zeiss Evo machine. The machine can evaluate element compositions on the material (AA5052) surface before and after being coated with AG layer. The analysis was conducted at several magnifications including $100 \mathrm{X}, 500 \mathrm{X}, 1 \mathrm{kX}, 5 \mathrm{kX}$, and $10 \mathrm{kX}$ to obtain a clear SEM image of each coated AA5052 and uncoated AA5052 surface.

\section{RESULTS AND DISCUSSION}

\section{EFFECT OF IMMERSING TIME ON THE CORROSION RATE OF AA5052}

Table 1 lists the immersion times for uncoated and AGcoated AA5052. The AA5052-15 plate coated with AG (EPD for $15 \mathrm{~min}$ ) was the best sample, as indicated by the lowest corrosion rate (CR) of $0.038173 \mathrm{mg} / \mathrm{cm}^{2} \mathrm{~h}$ and the highest inhibition efficiency (IE) of $60 \%$. The coated AA5052-30 and AA5052-45 plates (EPD for 30 and $45 \mathrm{~min}$ ) had corrosion rates and inhibition efficiencies of $0.0514 \mathrm{mg} / \mathrm{cm}^{2} \mathrm{~h}(48 \%)$ and $0.0466 \mathrm{mg} /$ $\mathrm{cm}^{2} \mathrm{~h}$ (53\%), respectively. AA5052-15 and AA505245 exhibited lower performance than AA5052-30. For 30 min of EPD, the AG layer onto the AA5052 surface was inhomogeneous and easy to detach because AG particles were not perfectly adsorbed onto the surface. For 15 min of EPD, AG particles were homogeneous and satisfactorily adsorbed on the AA5052 surface (Dalo et al. 2012). The AA5052 surface was fully covered by complex AG particles. For 45 min of EPD, AG particles on the AA5052 surface were very thick, causing the AG layer to easily detach because of the stronger interaction between fellow AG-AG particles than that of AG-AA5052. These phenomena resulted in easy detachment of the AG layer during EPD, as supported by the high CR (Table 1). Therefore, EPD immersion time plays a key role in obtaining coating surface with excellent performance.

TABLE 1. Immersion times for the uncoated and AG-coated AA5052

\begin{tabular}{cccc}
\hline Time EPD $(\mathrm{min})$ & Immersion time $(\mathrm{h})$ & $\mathrm{CR}\left(\mathrm{mg} / \mathrm{cm}^{2} \mathrm{~h}\right)$ & IE $(\%)$ \\
\hline \multirow{2}{*}{0} & 72 & 0.0409 & - \\
& 120 & 0.0645 & - \\
15 & 168 & 0.0984 & - \\
\hline \multirow{2}{*}{15} & 72 & 0.0073 & 79 \\
& 120 & 0.0238 & 63 \\
30 & 168 & 0.0381 & 60 \\
\hline \multirow{2}{*}{45} & 72 & 0.0159 & 61 \\
& 120 & 0.0313 & 51 \\
& 168 & 0.0514 & 48 \\
\hline & 12 & 0.0111 & 73 \\
& 120 & 0.0272 & 58 \\
\hline
\end{tabular}


EFFECT OF TEMPERATURE ON THE CORROSION RATE OF AA5052

AA5052-30 coated with AG exhibited excellent performance compared with the other samples and was selected for temperature studies. Table 2 lists the temperatures used during coating to determine their effect on the corrosion rate of uncoated and coated AA5052. Uncoated and coated AA5052 samples showed an increase in the corrosion rate with increasing temperature. At the same temperature, the corrosion rate of uncoated AA5052-0 was higher than that of the coated AA5052-
15. Increase in temperature can accelerate the anodic and cathodic reactions so AG layers on AA5052-15 will react easily with hydrogen gas $\left(\mathrm{H}_{2}\right)$ contained in the system; consequently, the AG layer will detach from the AA505215 surface. In addition, Table 2 shows that the inhibition efficiency decreased with increasing temperature. For instance, the inhibition efficiencies were 36.67 and $14.40 \%$ at 298 and $353 \mathrm{~K}$, respectively. Decrease in the inhibition efficiency with increasing temperature indicated the physical adsorption of AG particles onto the AA5052-15 surface.

TABLE 2. Effect of temperature on coated and uncoated AA5052

\begin{tabular}{cccc}
\hline \multicolumn{1}{c}{ Sample } & $\mathrm{T}(\mathrm{K})$ & $\mathrm{CR}\left(\mathrm{mg} / \mathrm{cm}^{2} \mathrm{~h}\right)$ & $\mathrm{IE}(\%)$ \\
\hline \multirow{2}{*}{ AA5052-0 } & 298 & 0.5 & - \\
& 313 & 0.73 & - \\
& 333 & 1.23 & - \\
\hline \multirow{2}{*}{ AA5052-15 + AG } & 353 & 1.97 & 36.67 \\
& 298 & 0.32 & 31.8 \\
& 313 & 0.5 & 23 \\
& 333 & 0.95 & 14.4 \\
\hline
\end{tabular}

\section{ACTIVATION ENERGY ANALYSIS}

Activation energy analysis was conducted to determine the minimum energy for activating AA5052-15 at different temperatures $(298,313,333$, and $353 \mathrm{~K})$. Figure 1 shows that the activation energy $\left(\mathrm{E}_{\mathrm{a}}\right)$ for the uncoated AA5052 was $21.8 \mathrm{~J} / \mathrm{mol}$, which was lower than that of AG-coated
AA5052 (26 J/mol). Higher $\mathrm{E}_{\mathrm{a}}$ indicates higher energy required to accelerate the corrosion reaction. Hence, as the temperature increases, the coating layer will deteriorate because the coating layer starts to degrade. Figure 1 also demonstrates that the uncoated AA5052 plate exhibited higher activation energy, resulting in faster corrosion occurrence compared with the coated AA 5051-15 plate.

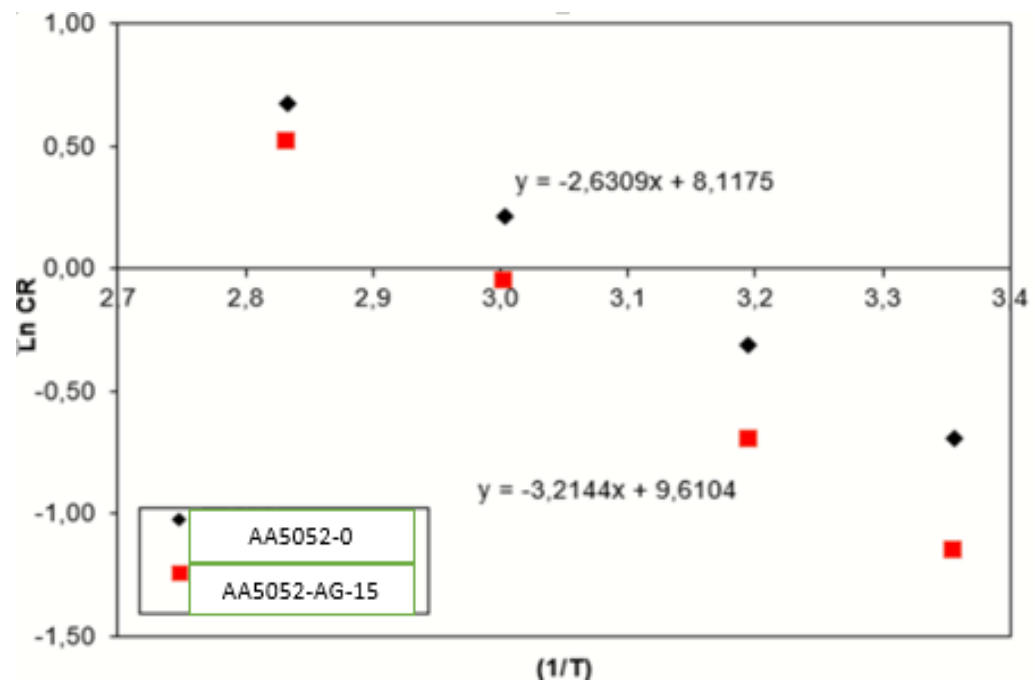

FIGURE 1. Plot of $\ln$ CR versus (1/T) for coated and uncoated AA5052 


\section{POLARIZATION POTENTIODYNAMIC ANALYSIS}

Corrosion rate was analyzed using the polarization potentiodynamic, in which the potential was set within $0.1 \mathrm{~V}$ to $-0.9 \mathrm{~V}$ at a scan rate of $2 \mathrm{mV} / \mathrm{s}$. Figure 2 and Table 3 shows the polarization potentiodynamic results for uncoated and coated AA5052. The corrosion potential $\left(\mathrm{E}_{\text {corr }}\right)$ and current density $\left(\mathrm{I}_{\text {corr }}\right)$ of the coated AA5052-15 were lower than those of the uncoated AA5052-0. The $I_{\text {corr }}$ values of the coated and uncoated AA5052 were 3.33 and $7 \mu \mathrm{A} / \mathrm{cm}^{2}$, respectively. In theory, corrosion rate was determined using $\mathrm{I}_{\text {corr }}$, that is, higher $\mathrm{I}_{\text {corr }}$ reflects higher corrosion rate. The current density of the uncoated AA5052 increased from 67 to $80 \mu \mathrm{A} / \mathrm{cm}^{2}$, and that of the coated AA5052-15 increased from 0.0075 to $20 \mu \mathrm{A} / \mathrm{cm}^{2}$. Hence, the increase in temperature can accelerate current flow from the anode to cathode, resulting in faster anodic and cathodic reactions. In addition, high temperatures can increase the activation energy, causing the AG layer to be eroded and increasing the corrosion rate (Ameh 2014; Arwati et al. 2018; Denni Asara et al. 2013). Hence, the temperature negatively affects the overall performance in terms of corrosion rate and inhibition efficiency (Arwati et al 2018; Gharavi et al. 2015).
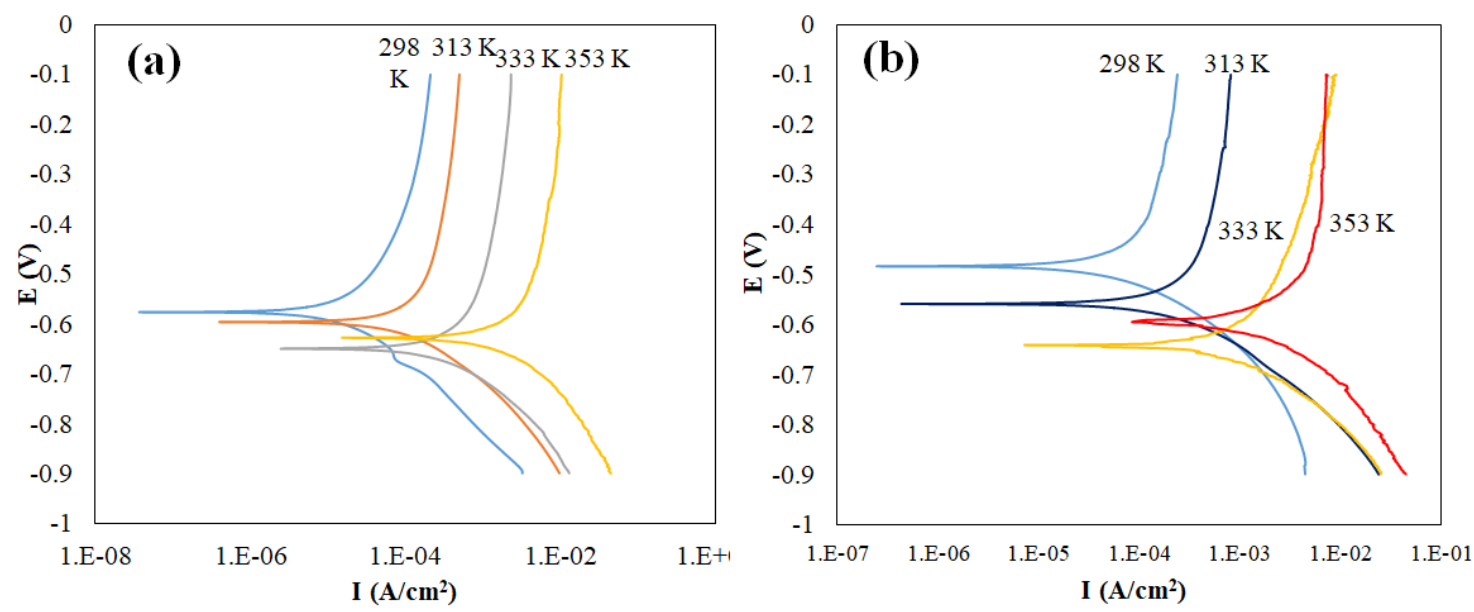

FIGURE 2. Polarization potentiodynamic graph for (a) uncoated and (b) coated AA5052

TABLE 3. Summary of polarization potentiodynamic results

\begin{tabular}{lccccc}
\hline Sample & $\mathrm{T}(\mathrm{K})$ & $\mathrm{I}_{\text {corr }}\left(\mu \mathrm{A} / \mathrm{cm}^{2}\right)$ & $\mathrm{E}_{\text {corr }}(\mathrm{mV})$ & $\mathrm{CR}(\mathrm{mpy})$ & $\mathrm{IE}(\%)$ \\
\hline & 298 & 67 & -481.91 & 62.91 & \\
\hline \multirow{2}{*}{ AA5052-0 } & 313 & 0.4 & -558.04 & 213.08 & \\
& 333 & 7 & -640.65 & 644.45 & \\
& 353 & 80 & -592.54 & 1215.31 & \\
\hline & 298 & 0.0075 & -575.97 & 10.7 & 81 \\
& 313 & 0.39 & -695.76 & 87.73 & 59 \\
& 333 & 3.33 & -650.45 & 321.81 & 50 \\
& 353 & 20 & -627.26 & 923.86 & 23
\end{tabular}




\section{ELECTROCHEMICAL IMPEDANCE STUDIES (EIS)}

Electrochemical impedance study (EIS) was conducted to identify corrosion resistance encountered by uncoated AA5052 and AG-coated AA5052 under acid sulfuric condition ( $0.5 \mathrm{M} \mathrm{H}_{2} \mathrm{SO}_{4}$ ). Figure 3(a) shows the bode plot result for uncoated and coated AA5052. The bode plot indicates that the uncoated AA5052 underwent constant change transfer resistance (Rp) due to corrosion occurrence. Figure 3(b) shows the Nyquist plot and its equivalent circuits, indicating that the uncoated AA5052 demonstrated lower electrochemical impedance at 529
$\Omega$ compared with the coated AA5052 at $795 \Omega$. The coated AA5052 showed higher phase angle of $75^{\circ}$ within the frequency region of $1-500 \mathrm{~Hz}$, and the uncoated AA5052 showed lower phase angle of $70^{\circ}$. The high phase angle of the coated AA5052 was due to the fact that AG coated the AA5052 plate, resulting in better capacitive value. The efficiency of the corrosion resistance of the coated AA5052 increased until 81\%, which was slightly higher than that of the conductive polymer poly p-phenylenediamine ( $0.06 \mathrm{M}$ pPD) that coated onto the SS316L surface with the efficiency of $59 \%$.
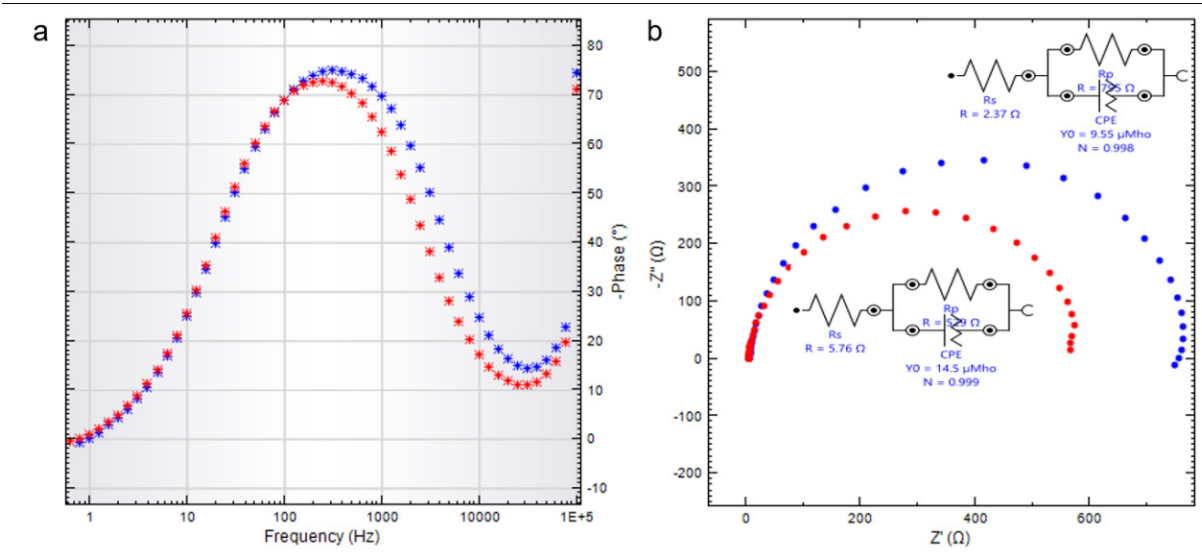

FIGURE 3. (a) Bode plots and (b) Nyquist plots and equivalent circuits of fitting EIS data for uncoated and AG-coated AA5052

\section{SURFACE MORPHOLOGY ANALYSIS}

Figure 4 shows the morphology of uncoated AA5052-0 and coated AA5052-15 under immersed condition for 168 $\mathrm{h}$ and under un-immersed condition. Figure 4(a) shows that the uncoated AA5052-0 has a smother and brighter surface in contrast to the coated AA5052-15 (Figure 4(b)). These findings indicated that the uncoated AA5052 plate were successfully coated with AG through EPD. Figure 4(c) shows the uncoated AA5052 plate immersed for 168 h. A large black pore was formed on the AA5052 surface. This phenomenon showed the occurrence of corrosion in certain local areas known as pitting corrosion. Figure 4(d) shows the smooth surface of the coated AA5052-15 with no evidence of corrosion. The layer covering the AA5052 plate surface demonstrated a fine pore, indicating the possibility that AG layer was absorbed onto the AA5052 plate surface and resulted in physical inhibitor efficiency of $60 \%$.
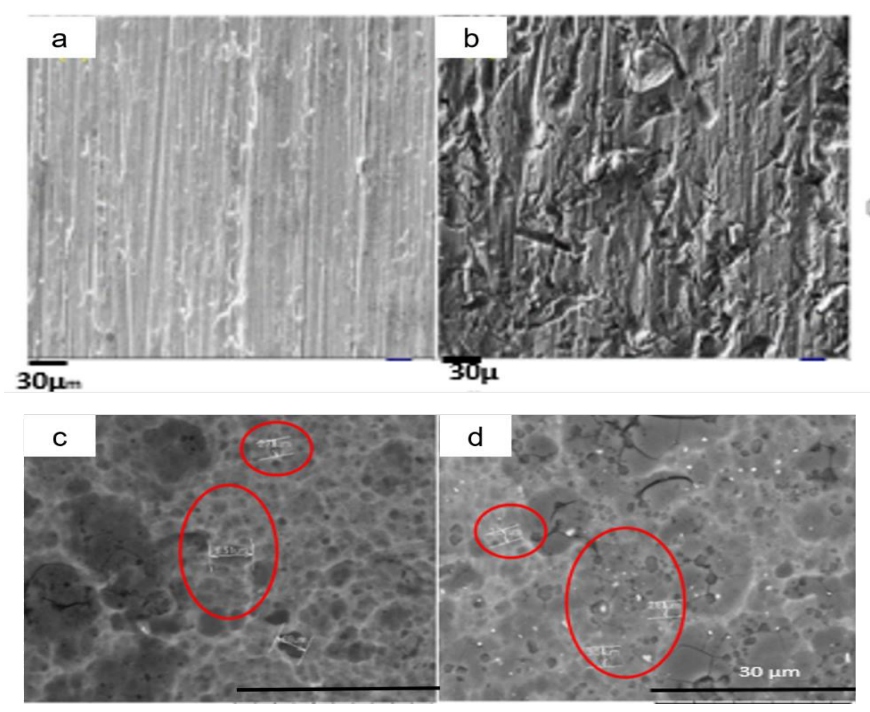

FIGURE 4. SEM images of (a) uncoated AA5052-0, (b) coated AA5052-15, (c) uncoated AA5052-0 immersed for $168 \mathrm{~h}$, and (d) coated AA5052-15 immersed for $168 \mathrm{~h}$ 
The thickness of the coated material is crucial because it affects the overall bipolar plate performance. In the SEM analysis, the thickness of the coated AA5052-15 plate varied (Figure 5), in which the thin coating layer was recorded within 6.31-18.00 $\mu \mathrm{m}$. By contrast, other studies reported the thickened coated layer at $40 \mathrm{~mm}$ when aluminium alloy 6061 was coated with PANI through physical vapor deposition (PVD). In theory, EPD can deposit particles on the material surface with thickness ranging from 1.0 to $100 \mu \mathrm{m}$ (Besra \& Liu 2007; Boccacini et al. 2010; González Gutiérrez et al. 2018).

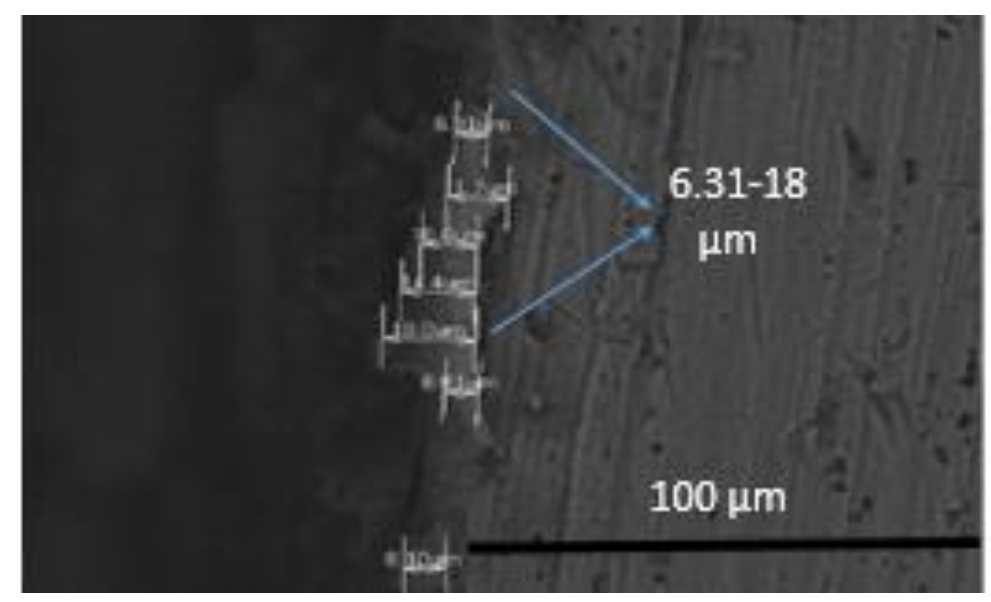

FIGURE 5. SEM images for the thickness of AG layer on AA5052-15+AG

Figure 6(a) shows the uncoated AA5052 surface with slight damage due to temperature rise, thereby accelerating the anodic and cathodic reactions. This finding indicated the formation of less homogeneous surfaces in some areas on the uncoated AA5052 surface (Figure 6(a)). The coated AA5052-15 had a porous smooth surface with no obvious damage to metal surfaces.

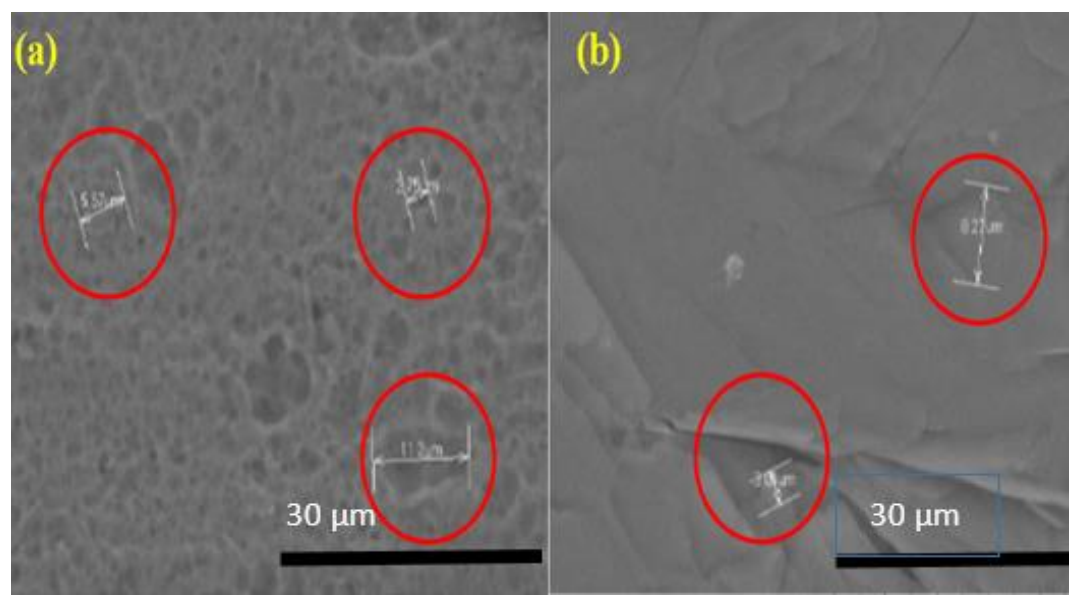

FIGURE 6. SEM images for (a) uncoated AA5052-0 and (b) coated AA5052-15 after immersed in acidic solution $\left(0.5 \mathrm{M} \mathrm{H}_{2} \mathrm{SO}_{4}\right)$ and heated at $353 \mathrm{~K}$ 


\section{CONCLUSION}

The corrosion rate of the uncoated and AG-coated AA5052-15 in acidic solution $\left(0.5 \mathrm{M} \mathrm{H}_{2} \mathrm{SO}_{4}\right)$ was recorded at $0.984 \mathrm{mg} / \mathrm{cm}^{2} \mathrm{~h}$ and $0.381 \mathrm{mg} / \mathrm{cm}^{2} \mathrm{~h}$ for 168 $\mathrm{h}$ of immersion. The optimum condition for AG coating through EPD was 15 min with $20 \mathrm{~V}$ of applied voltage. The corrosion rates of the uncoated and coated AA50520 were 1.97 and $1.68 \mathrm{mg} / \mathrm{cm}^{2} \mathrm{~h}$, respectively. Based on the polarization potentiodinamic tests, the temperature rise resulted in higher corrosion rate with $1215.31 \mathrm{mpy}$ for uncoated AA5052-0 and 923.86 mpy for coated AA5052-15 at $353 \mathrm{~K}$. The AG-coated AA5052 exhibited excellent performance by reducing and inhibiting corrosion under acidic condition while maintaining the thin coating layer ranging from 6.31 to $18.0 \mu \mathrm{m}$.

\section{ACKNOWLEDGEMENTS}

The authors would like to thank Universiti Kebangsaan Malaysia (UKM) (Grant PP-SELFUEL-2020) and Mercubuana University, Indonesia (UMB) for facilities and support.

\section{REFERENCES}

Ameh, P.O. 2014. Inhibitory action of Albizia zygia gum on mild steel corrosion in acid medium. African Journal of Pure and Applied Chemistry 8(2): 37-46.

Arwati, I.A., Majlan, E.H., Daud, W.R.W., Shyuan, L.K., Arifin, K., Husaini, T., Alva, S. \& Radzuan, N.A.M. 2019. Electrophoresis deposition Arabic Gum effect on aluminum 5052 reduce corrosion. Sains Malaysiana 48(2): 401406.

Arwati, I.A., Majlan, E.H., Daud, W.R.W. \& Alva, S. 2018. Temperature effects on stainless steel 316L corrosion in the environment of sulphuric acid $\left(\mathrm{H}_{2} \mathrm{SO}_{4}\right)$. IOP Conference Series: Materials Science and Engineering 343(012016): $1-8$.

Azzaoui, K., Mejdoubi, E., Jodeh, S., Lamhamdi, A., RodriguezCastellón, E., Algarra M., Zarrouk, A., Errich, A., Salghi, R. \& Lgaz, H. 2017. Eco friendly green inhibitor Gum Arabic (GA) for the corrosion control mild steel in hydrochloric acid medium. Corrosion Science 129: 70-81.

Besra, L. \& Liu, M. 2007. A review on fundamentals and applications of electrophoretic deposition (EPD). Progress in Materials Science 52(1): 1-61.

Bhowmik, A., Srivas, S.P. \& Khandelwal, A.K. 2016. A review of the properties aluminium alloy 5052. Journal of Scientific Research in Allied Science 2(2) 25-30.

Boccacini, A.R., Keim, S., Ma, R., Li, Y. \& Zhitomirsky, I. 2010. Review: Electrophoretic deposition of biomaterials. Journal of the Royal Society Interface 7(5): 581-613.

Chiang, T.Y., Su, A., Tsai, L.C., Sheu, H.H. \& Lu, C.E. 2014. Corrosion resistance of 5052 Al-alloy with a Zirconia-rich conversion coating used in bipolar plates in PEMFCs. International Journal of Electrochemical Science 9: 58505863.
Choudhary, B., Anwar, S., Besra, L. \& Anwar, S. 2017. Electrophoretic deposition studies of $\mathrm{Ba}(\mathrm{Zr}-\mathrm{Ce}-\mathrm{Y}) \mathrm{O}_{3}$ ceramic coating. International Journal of Applied Ceramic Technology 16(3): 1022-1031.

Dalo, M.A., Othman, A. \& Al-Rawashdeh, N.A.F. 2012. Exudate gum from acacia trees as green corrosion inhibitor for mild steel in acidic media. International Journal of Electrochemical Science 7: 9303-9324

Dariva, C.G. \& Galio, A.F. 2014. Corrosion inhibitors - principles, mechanisms and applications. In Developments in Corrosion Protection, edited by Aliofkhazraei, M. Rijeka: InTech. pp. 365-379.

Denni Asara Awizar, Norinsan Kamil Othman, Azman Jalar, I. Abdul Rahman \& N.H. Al-hardan. 2013. Nanosilicate extraction from rice husk ash green corrosion inhibitor. Journal of Elechtrochemical Science 8: 1759-1769.

Gharavi, F., Matori, K.A., Yunus, R., Othman, N.K. \& Fadaeifard, F. 2015. Corrosion behavior of Al6061 alloy weldment produced by friction stir welding process. Journal of Materials Research and Technology 4(3): 314-322.

González Gutiérrez, A.G., Sebastian, P.J., Magallón Cacho, L., Borja Arco, E., Campos, J. \& Baron, A. 2018. Surface modification of aluminum alloy 6061 for bipolar plate application: Adhesion characteristics and corrosion resistance. International Journal of Electrochemical Science 13: 3958-3969.

Huang, N.B., Yu, H., Xu, L.S., Zhan, S., Sun, M. \& Kirk, D.W. 2016. Corrosion kinetics of $316 \mathrm{~L}$ stainless steel bipolar plate with chromium carbide coating in simulated PEMFC cathodic environment. Results in Physics 6: 730736.

Khan, G., Kazi, S.N., Basirun, W.J., Ali, H.B.M., Faraj, F.L. \& Khan, G.M. 2015. Application of natural product extracts as green corrosion inhibitors for metals and alloys in acid pickling processes - a review. International Journal of Electrochemical Science 10: 6120-6134.

Pech-Rodríguez, W.J., González-Quijano, D., Vargas-Gutiérrez, G. \& Rodríguez-Varela, F.J. 2014. Electrophoretic deposition of polypyrrole/Vulcan XC-72 corrosion protection coatings on SS-304 bipolar plates by asymmetric alternating current for PEM fuel cells. International Journal of Hydrogen Energy 39(29): 16740-16749.

Sagir Alva, Aiman Sajidah binti Abdul Aziz, Mohd Ismahadi bin Syono \& Wan Adil bin Wan Jamil. 2018. Ag/AgCl reference electrode based on thin film of Arabic Gum membrane. Indonesian Journal of Chemistry 18(3): 479-485.

Sutharssan, T., Montalvao, D., Kang, Y., Wang, W., Pisac, C. \& Elemara, H. 2017. A review on prognostics and health monitoring of proton exchange membrane fuel cell. Renewable and Sustainable Energy 75: 440-450

Taherian, R. 2014. A review of composite and metallic bipolar plates in proton exchange membrane fuel cell: materials, fabrication, and material selection. Journal of Power Sources 265: 370-390

Umoren, S.A. \& Eduok, U.M. 2016. Application of carbohydrate polymers as corrosion inhibitors for metal substrates in different media: A review. Carbohydrate Polymer 140: 314-341. 
Vadivelan, M.R., Kumar, N.S. \& Balaji, R. 2015. A review on corrosion of metallic bi-polar plates for proton exchange membrane (PEM) fuel cells. IOSR Journal of Mathematics 11(6): 83-99.

Yang, Y., Guo, L.J. \& Liu, H. 2011. Corrosion characteristics of SS316L as bipolar plate material in PEMFC cathode environments with different acidities. International Journal of Hydrogen Energy 36(2): 1654-1663.

Zhang, D., Duan, L., Guo, L., Wang, Z., Zhao, J., Tuan, W.H. \& Niihara, K. 2011. TiN-coated titanium as the bipolar plate for PEMFC by multi-arc ion plating. International Journal of Hydrogen Energy 36(15): 9155-9161.

I Gusti Ayu Arwati, Edy Herianto Majlan*, Loh Kee Shyuan \& Teuku Husaini

Fuel Cell Institute

Universiti Kebangsaan Malaysia

43600 UKM Bangi, Selangor Darul Ehsan

Malaysia
Nabilah Afiqah Mohd Radzuan

Centre for Materials Engineering and Smart Manufacturing

Faculty of Engineering and Built Environment

Universiti Kebangsaan Malaysia

43600 UKM Bangi, Selangor Darul Ehsan

Malaysia

I Gusti Ayu Arwati, Sagir Alva \& Muhajirin

Engineering Faculty

Mercu Buana University

11650 Jakarta Barat

Indonesia

*Corresponding author; email: edyhm71@gmail.com

Received: 4 August 2020

Accepted: 11 September 2020 